[RAdjocarbon, Vol. 16, No. 3, 1974, P. 368-380]

\title{
SOUTHERN METHODIST UNIVERSITY RADIOCARBON DATE LIST I
}

\author{
VANCE HAYNES and HERBERT HAAS
}

Department of Geological Sciences, Southern Methodist University, Dallas, Texas 75275

\section{INTRODUCTION}

The SMU Radiocarbon Laboratory is operated by the Department of Geological Sciences within the Institute for the Study of Earth and Man. One laboratory room contains the benzene synthesis system where samples are pretreated and converted to $\mathrm{CO}_{2}$ in a standard way and gas is purified after the procedures of Broecker (1957) by passage through hot $\mathrm{CuO}, 10 \% \mathrm{AgNO}_{3}$ solution, chromic acid, hot copper, and $\mathrm{P}_{2} \mathrm{O}_{5}$ via cryogenic pumping with liquid nitrogen. Purified $\mathrm{CO}_{2}$ is then converted to $\mathrm{Li}_{2} \mathrm{C}_{2}$ which is hydrolized to $\mathrm{C}_{2} \mathrm{H}_{2}$ and converted to $\mathrm{C}_{6} \mathrm{H}_{6}$ catalytically following the procedures of Noakes et al (1966). Carbon dioxide and benzene yields are routinely in excess of $90 \%$ in both cases.

Liquid scintillation counting is performed in a separate room utilizing a lead-shielded Intertechnique LS-20 counter optimized for handling $3 \mathrm{ml}$ of benzene. Principle innovations in optimizing the counter were 1) lining the sample chamber with ca $1 \mathrm{~cm}$ "quiet" lead to accommodate 2) a pure quartz spectrophotometric cell as counting vial, and 3) adding the scintillator as a precisely weighed powder $(0.91 \%$ butyl PBD) directly to the sample benzene, thus eliminating the dilution of the sample by a scintillator solution. All samples are transfered via syringe to reduce contact with oxygen.

The count rate for the NBS oxalic acid radiocarbon dating standard is ca $23 \mathrm{cpm}$ (specific activity $=8.92 \mathrm{cpm} / \mathrm{gC}$ ) and the background count, using benzene produced from Pennsylvanian anthracite is ca $3 \mathrm{cpm}$ yielding a figure of merit $\left(\mathrm{S}^{2} / \mathrm{B}\right)$ of 143 . One to 4 unknown samples are counted between counting runs of background and standard which are statistically averaged for calculating the ages. All samples are counted for at least $1400 \mathrm{~min}$ and monitored by printouts every $100 \mathrm{~min}$.

The liquid scintillation counting and benzene conversion systems which will be described in detail elsewhere (Haas \& Haynes) have been in operation since the fall of 1972 and routine age analyses were begun in January 1973. Several months of analyzing standards, backgrounds, and samples of known age reveal a high degree of precision and reliability in all systems. Prior to 1973,130 samples pretreated at SMU were analyzed and dated at the University of Texas radiocarbon laboratory and appear in Valastro et al (in press).

The complete methane conversion and counting system of the Mobil Field Research Laboratories was donated to Southern Methodist University and is now a part of our radiocarbon dating facilities at the Institute for the Study of Earth and Man. After installation, testing, and dating of the first eleven samples (SMU-1-11) the $\mathrm{CH}_{4}$ system was shut down for 
repairs and modifications, and current plans are to optimize it for the $\mathrm{CO}_{2}$ counting of very small samples.

\section{ACKNOWLEDGMENTS}

The SMU Radiocarbon Laboratory was created through the generosity and forethought of the late William B Heroy, who provided the space and most of the equipment for which we are most grateful. Claude C Albritton, James E Brooks, William B Heroy, Jr, and Fred Wendorf promoted the laboratory within the Institute for the Study of Earth and Man, and without their wholehearted support it could not have been established. Michael J Holdaway provided controlled heating equipment and collaborated in the initial experiments in pyrolyzing bone samples.

E Mott Davis and Sam Valastro, Texas Memorial Museum, arranged analysis and dating of our samples before 1973 at the University of Texas laboratory. Close cooperation has been maintained between the two laboratories and special gratitude is due Sam Valastro and Alejandra G Varela for their help and advice in constructing our benzene synthesis system.

We gratefully acknowledge the gift of the Mobil Field Research Laboratory's methane dating system and thank S M Foulks and J S McNiel, Mobil Research and Development Corp, and Fred Wendorf, SMU for arranging this. John R Cooper, Operator of the Mobil Lab, assisted us in setting up the equipment and dating the first samples.

Indispensible technical assistance in the field and laboratory was provided by Steven Haney, Don Henry, Afifa Hassan, Nancy Neubert, Joe Davis, and Robert Leeper and secretarial work was provided by Marlene Altman, Elise Murphy, and Barbara Doolin. Financial support is provided by the Institute for the Study of Earth and Man, the National Science Foundation (Grants GA-12772 and GA-35625), and the National Geographic Society, which sponsored six years of archaeologic excavations at the Murray Springs Clovis site in Arizona.

Finally, to Paul E Damon and Austin Long, University of Arizona, the senior author is indebted for invaluable experience in the fine points of radiocarbon dating.

\section{SAMPLE DESCRIPTIONS}

The samples are classified into (I) Geochemical Samples, (II) Geochronolgic Samples, and (III) Archaeologic Samples. Under the first heading are samples analyzed not for dating per se but for calibration, interlaboratory checks, isotopic content, and tests for contamination or geochemical alteration. Where such samples are a part of a series of dated samples they are included with the series under Geochronologic Samples. The latter are all those analyzed primarily for dating purposes and include paleoecologic samples. Archaeological samples are listed separately and all samples are subheaded by geographic area. 
Sample of unknown provenience subm 1972 by Henry F Nelson, Mobil Field Research Lab. Analyzed for possible contamination by organic substances of Modern age. Comment: sample is uncontaminated within limits of detectability.

\section{SMU-12. Spruce wood}

$11,850 \pm 70$ 9900 BC

SMU-16. Spruce wood

$11,740 \pm 140$ $9790 \mathrm{BC}$

Sample from Appleton, Wisconsin, $4.2 \mathrm{~m}$ below plain of glacial Lake Oshkosh $\left(44^{\circ} 24^{\prime} \mathrm{N}, 88^{\circ} 25^{\prime} \mathrm{W}\right)$ run as interlaboratory check with Tx-541, 11,620 \pm 80 on same wood specimen. Should be same age as Two Creeks Forest Bed. Comment: agrees well with other dates summarized with Tx-541 (R, 1970, v 12, pp 249-250).

\section{SMU-13. Greenwade House, B}

Wood from foundation post of pioneer $\log$ cabin built in middle $1850^{\prime} \mathrm{s}$ in Brazos $\mathrm{R}$ valley near Whitney, Texas (31 $54^{\prime} \mathrm{N}, 97^{\circ} 23^{\prime} \mathrm{W}$ ) run as an interlaboratory check with Tx-540, $120 \pm 50$ on the same wood specimen (R, 1970, v 12, p 249).

\section{GEOCHRONOLOGIC SAMPLES}

\section{A. Arizona}

Murray Springs site $\left(31^{\circ} 34^{\prime} 15^{\prime \prime} \mathrm{N}, 110^{\circ} 10^{\prime} 38^{\prime \prime} \mathrm{W}\right)$, San Pedro Valley, Cochise Co, Arizona (Ariz: EE:8:25) is a buried Clovis hunting camp and kill site where artifacts assoc with mammoth, bison, and horse occur within a sequence of late Quaternary sediments (Haynes \& Hemmings, 1968; Hemmings, 1970). Samples are classified in stratigraphic order by geologic unit. Investigations supported by Natl Geog Soc (Archaeol) and Natl Sci Foundation (Geol). Coll 1966-1973 and subm by C V Haynes.

\section{Murray Springs Unit $F_{1}$ series}

Unit $F_{1}$ (Graveyard sand member, Lehner formation) is a coarse sand and gravel channel deposit of a small stream along which mammoth and bison were killed by Clovis hunters. Remains of extinct forms of horse and camel occur in lower portions of channel fill but not in upper part where Clovis artifacts are concentrated. Charcoal dated from several occurrences to determine time range of deposition. A-805, 11,230 \pm 340 ( $R, 1967, \mathrm{v} 9, \mathrm{p} 1 \mathrm{l})$ is from same unit.

SMU-17. Charcoal, Loc 1, Sq C4

SMU-18. Charcoal, Loc 2, Sq F2
$8770 \pm 70$ $6820 \mathrm{BC}$

$$
11,730 \pm 180
$$$$
9780 \text { BC }
$$ 
SMU.41. Charcoal, Loc 2, Sq E3

$10,840 \pm 70$

$\mathbf{8 8 9 0}$ вC

SMU-42. Charcoal, Loc 2, Sq E1

$10,840 \pm 140$

8890 BC

SMU-43. Humates from SMU-42

$11,160 \pm 110$

9210 BC

SMU-19. Humates, Trench 28

$10,740 \pm 190$ 8790 BC

SMU-29. Humates, Trench 28

$10,790 \pm 150$ 8840 BC

SMU-27. Charcoal, Trench 20

$10,890 \pm 180$ 8940 BC

SMU-28. Humates from SMU-27

$11,210 \pm 200$ 9260 BC

Comment: all except SMU-17 indicate a millennium or less for deposition of Unit $\mathrm{F}_{1}$. SMU-17 was analyzed after treatment with preservative for wood identification tests at College Agric, Univ Arizona. All Unit $\mathrm{F}_{1}$ wood identifications are ash (Fraxinus sp).

\title{
Murray Springs Unit E series
}

Unit E, Coro marl member, Murray Springs formation, is a pond or emergent water table deposit of calcium carbonate that dried up and was eroded by Unit $F_{1}$ channel prior to deposition of Graveyard sand. Previous dates on carbonate $\mathrm{CO}_{2}$ (Valastro et al, in press) overlap with dates on more reliable charcoal from younger units indicating contamination by exchanged $\mathrm{CO}_{2}$. This series was run on organic carbon residue recovered after pyrolysis followed by acid removal of carbonates. Uppermost sample (\#2) occurred $20 \mathrm{~cm}$ below eroded upper contact and lowermost sample (\#11) occurred $20 \mathrm{~cm}$ above basal contact of a $2 \mathrm{~m}$ sec of marl exposed in S wall of S branch of Curry Draw 70m E of Loc 1, Stake AO.

\author{
SMU-33. Residue \#2 \\ SMU.34. Residue \#4 \\ SMU.35. Residue \#6 \\ SMU.36. Residue \#8 \\ SMU.37. Residue \#10
}

$11,880 \pm 250$ 9930 BC $13,980 \pm 190$ 12,030 BC $18,060 \pm 150$ $16,110 \mathrm{BC}$

$16,810 \pm 420$ $14,860 \mathrm{BC}$ 
SMU-38. Residue \#11

Comment: all ages should be considered minimum due to possible contamination by organic matter from overlying soil.

SMU.39. Curry Draw, Unit $\mathbf{G}_{3}$

$$
\begin{array}{r}
500 \\
\text { AD } 1450
\end{array}
$$

Charcoal from base of $2.4 \mathrm{~m}$ alluvial terrace exposed in $\mathrm{N}$ bank of Curry Draw opposite Murray Springs homestead $\left(31^{\circ} 34^{\prime} 20^{\prime \prime} \mathrm{N}, 110^{\circ}\right.$ $10^{\prime} 05^{\prime \prime}$ W) $13 \mathrm{~km} \mathrm{E}$ of Sierra Vista, Cochise Co, Arizona. Coll and subm 1972 by $\mathrm{C}$ V Haynes. Comment: dates beginning of youngest alluvial fill prior to modern arroyo cutting.

SMU-40. Curry Draw, Unit $\mathbf{G}_{2 \mathrm{a}}$

$3190 \pm 80$

Charcoal from hearth $1.2 \mathrm{~m}$ below surface of $2.4 \mathrm{~m}$ alluvial terrace and $3 \mathrm{~m}$ below contact with overlying Unit $\mathrm{H}$ exposed in $\mathrm{N}$ bank of Curry Draw $1.5 \mathrm{~km}$ W of Lewis Springs ( $31^{\circ} 31^{\prime} 50^{\prime \prime} \mathrm{N}, 110^{\circ} 09^{\prime} 05^{\prime \prime} \mathrm{W}$ ), Cochise Co, Arizona. Coll 1972 and subm by $\mathrm{L}$ Escapule and $\mathrm{C}$ V Haynes. Comment: dates upper part of Unit Ga (McCool member, Escapule formation).

\section{SMU-47. Contention hearth (24-4)}

$1100 \pm 110$

Charcoal from hearth $1.5 \mathrm{~km}$ below surface of $2.4 \mathrm{~m}$ alluvial terrace along unnamed arroyo at Contention $\left(31^{\circ} 40^{\prime} \mathrm{N}, 110^{\circ} 12^{\prime} \mathrm{W}\right)$ Cochise Co, Arizona. Coll and subm 1972 by $\mathrm{N}$ Johnson and $\mathrm{C}$ V Haynes. Comment: alluvium is equivalent to Unit $\mathrm{G}_{2 \mathrm{zb}}$ at Murray Springs.

\section{SMU-45. Contention hearth (24-3)}

$3070 \pm 60$

Charcoal from rock hearth $1 \mathrm{~m}$ below surface of $8 \mathrm{~m}$ alluvial terrace of San Pedro R at Contention (31 $46^{\prime} \mathrm{N}, 110^{\circ} 12^{\prime} \mathrm{W}$ ) Cochise Co, Arizona. Coll and subm 1972 by $\mathrm{N}$ Johnson and C V Haynes. Comment: dates near end of deposition of intermediate of 3 alluvial fills equivalent to Unit $G$ at Murray Springs.

\section{SMU.46. Horsethief Draw hearth (24-9)}

$1150 \pm 50$ AD 800

Charcoal from hearth with Hohokam potsherds $0.5 \mathrm{~m}$ below surface of $3.7 \mathrm{~m}$ terrace exposed by $\mathrm{N}$ bank Horsethief Draw $\left(31^{\circ} 31^{\prime} 30^{\prime \prime} \mathrm{N}\right.$, $110^{\circ} 08^{\prime} 53^{\prime \prime}$ W) Cochise Co, Arizona. Coll and subm 1972 by L Escapule and $\mathrm{C}$ V Haynes. Comment: equivalent to Unit $\mathrm{G}_{2 \mathrm{~b}}$ at Murray Springs.

\section{Winkelman Hearth ( BB :2:13) series, Arizona}

SMU-48. Hearth \#3 (13-33)

$4490 \pm 70$

$9.2 \mathrm{~m}$ below terrace surface, $\mathrm{N}$ wall. 
SMU-54. Hearth \#2 (13-32)

$8.3 \mathrm{~m}$ below terrace surface, $\mathrm{S}$ wall.

1990 вC

Charcoal from $13 \mathrm{~m}$ alluvial terrace exposed in arroyo crossing Hwy $77 \mathrm{ca} 14 \mathrm{~km} \mathrm{~S}$ of Winkleman $\left(32^{\circ} 52^{\prime} \mathrm{N}, 110^{\circ} 43^{\prime} \mathrm{W}\right)$ Pinal Co, Arizona. Coll and subm 1972 by J E Ayres and C Cronin. Comment: equivalent to Unit $\mathrm{G}_{1}$ at Murray Springs.

SMU.59. Escapule hearth $930 \pm 50$

Charcoal exposed in colluvium $0.3 \mathrm{~m}$ below surface exposed by a rill $2.4 \mathrm{~km} \mathrm{NW}$ of Lewis Springs $\left(31^{\circ} 36^{\prime} \mathrm{N}, 110^{\circ} 10^{\prime} \mathrm{W}\right)$ Cochise Co, Arizona. Coll and subm 1972 by L Escapule and C V Haynes.

SMU-15. Boquillas hearth

$\mathbf{3 9 0} \pm \mathbf{5 0}$

Charcoal from rock hearth on intermediate terrace $1.4 \mathrm{~km} \mathrm{E}$ of abandoned Boquillas RR sta $\left(31^{\circ} 47^{\prime} \mathrm{N}, 110^{\circ} 13^{\prime} \mathrm{W}\right)$ Cochise Co, Arizona. Coll and subm 1970 by L Escapule and C V Haynes.

Frazier site series

$$
\text { B. Colorado }
$$

SMU-32. Humates, lst extraction

\section{SMU-31. Humates, 2nd extraction}

$$
9550 \pm 130
$$

$7600 \mathrm{BC}$

$9650 \pm 130$

7700 BC

Average $9600 \pm 130$

Buried dark gray organic soil horizon on gray sandy clay exposed in W wall of ravine cutting through Frazier Agate Basin site (Loc 2) on Kersey terrace $2 \mathrm{~km}$ NW Kersey $\left(40^{\circ} 22^{\prime} \mathrm{N}, 104^{\circ} 35^{\prime} \mathrm{W}\right)$ Weld Co, Colorado. Coll and subm 1966 by C V Haynes. Comment: date is probably minimum for Agate Basin horizon.

\section{Florida}

\section{SMU-14. Aucilla peat}

$37,880 \pm 2000$ 35,930 BC

Lower $1 / 3$ of $5 \mathrm{~m}$ core from bottom of Aucilla R $1.6 \mathrm{~km} \mathrm{SW}$ of Nutall Rise $\left(30^{\circ} 08^{\prime} \mathrm{N}, 83^{\circ} 95^{\prime} \mathrm{W}\right)$ Jefferson Co, Florida. Numerous bones of extinct Pleistocene animals and artifacts, some paleo-Indian, were on river bottom 5 to $10 \mathrm{~cm}$ depth. Coll and subm 1972 by $\mathrm{R}$ Ohmes, Chairs, Florida, and L Workman and A R Saltus, Jr, Florida Dept of State, Tallahassee. Comment (CVH): sample predates fauna and culture.

\section{Missouri}

\section{SMU-78. Philips Spring}

$7870 \pm 90$

Wood fragments from clayey peat $310 \mathrm{~cm}$ below surface of $8 \mathrm{~m}$ alluvial terrace of Pomme de Terre R at Philips ford $\left(38^{\circ} 03^{\prime} 37 ; \mathrm{N}, 93^{\circ} 19^{\prime}\right.$ 
10" W) Hickory Co, Missouri. Coll and subm 1973 by C V Haynes. Comment: dates upper part of alluvium correlated with that at Rodgers Shelter (Wood \& McMillan, 1974).

\section{Hudson-Meng series}

$$
\text { E. Nebraska }
$$

SMU.49. Bone carbonate $\mathrm{CO}_{2}$ \# $\mathrm{I}$

SMU-50. Bone carbonate $\mathrm{CO}_{2} \# 2$

\section{SMU-51. Bone apatite $\mathrm{CO}_{2} \# \mathbf{I}$}

$115.3 \pm 1.0 \%$ modern $109.8 \pm 1.4 \%$ modern

$8520 \pm 110$ $6570 \mathrm{BC}$

$8990 \pm 190$ 7040 BC

SMU-52. Bone apatite $\mathrm{CO}_{2} \# 2$

Bone from extinct bison at Hudson-Meng paleo-Indian site $22 \mathrm{~km}$ NW of Crawford $\left(42^{\circ} 49^{\prime} \mathrm{N}, 103^{\circ} 36^{\prime} \mathrm{W}\right)$ Sioux Co, Nebraska. Bone treated to separate successive stages of $\mathrm{CO}_{2}$ first from secondary calcite and then from apatite. Coll and subm 1971-73 by L D Agenbroad, Chadron State College. Comment: each successive stage is older suggesting that last stage is less contaminated.

\section{Sandia Cave series}

\section{F. New Mexico}

SMU-76. Wood (Pinus sp)

SMU-77. Charcoal

Samples from rodent deposit within older deposits of Sandia Cave $\left(35^{\circ} 15^{\prime} 30^{\prime \prime} \mathrm{N}, 106^{\circ} 24^{\prime} \mathrm{W}\right) 28 \mathrm{~km} \mathrm{NW}$ of Albuquerque, Sandoval Co, New Mexico.

\section{North Sulphur River series}

$$
\text { G. Texas }
$$

Samples from alluvium underlying flood plain of $\mathrm{N}$ Sulphur $\mathrm{R}$ in vicinity of Ben Franklin, Delta Co, Texas. Coll and subm by M Rainey, Southern Methodist Univ. Previous investigations by Slaughter and Hoover (1963).

\section{SMU-62. Mussel shells}

$2840 \pm 60$

Shells from Unit $B_{2} 1.6 \mathrm{~m}$ above contact with Unit $B_{1}$ exposed in right bank Sulphur R $2.4 \mathrm{~km} \mathrm{NE}$ of Ben Franklin $\left(33^{\circ} 20^{\prime} 35^{\prime \prime} \mathrm{N}, 95^{\circ}\right.$ $45^{\prime} 10^{\prime \prime} \mathrm{W}$ ).

\section{SMU-70. Charcoal}

\section{AD 1290}

$660 \pm 70$

Dispersed charcoal from late alluvium exposed by left bank of Ghost

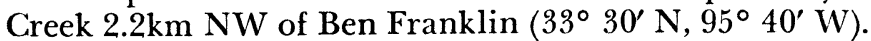


SMU-71. Charcoal

$1790 \pm 50$

Dispersed charcoal from base of Unit $B_{1}$ on truncated soil exposed in right bank Sulphur R $1.3 \mathrm{~km}$ N of Ben Franklin $\left(33^{\circ} 29^{\prime} 40^{\prime \prime} \mathrm{N}, 95^{\circ}\right.$ $\left.45^{\prime} 55^{\prime \prime} \mathrm{W}\right)$

\section{Bir Sahara series}

\section{H. Egypt}

Sediments containing Pleistocene faunas and artifacts exposed in a deflation basin at Sahara well in Western Desert $375 \mathrm{~km} \mathrm{~W}$ of Abu Simbal on the Nile R $\left(22^{\circ} 52^{\prime} \mathrm{N}, 28^{\circ} 36^{\prime} \mathrm{E}\right)$. Carbonate fraction of mollusk shells analyzed. Coll 1973 by C V Haynes and subm. by F Wendorf.

\section{SMU-75. Pelecypod shells}

$30,870 \pm 1000$

From desert surface and underlying lacustrine silt at Loc BS-15.

\section{SMU-79. Gastropod shells}

High-spired snail shells from lacustrine silt of younger ponding interval 20 to $50 \mathrm{~cm}$ below surface at Loc BS-15. Comment: date of SMU-79 indicates that shells from surface in SMU-75 were contaminated, probably by exchange with atmospheric $\mathrm{CO}_{2}$, despite strong acid leaching prior to analysis. Aterian horizon at Bir Tarfawi $11 \mathrm{~km} \mathrm{E}$ is tentatively correlated with these beds.

\section{SMU.80. From surface (BS-13)}

\section{SMU-82. Coll by flotation (BS-16)}

SMU-81. Hand picked large specimens (BS-16)

$>41,450$ ing ing interval. Stratigraphically below silt of SMU-79. Comment: results indicate contamination by exchange and secondary calcification can be avoided if high-spired shells are crushed and fragments selected for ultrasonic cleaning and leaching. Series indicates both Aterian and Mousterian occupations were prior to $44,680 \mathrm{BP}$.

\section{Ethiopia}

The archaeology and Quaternary geology of the Gala Lakes region of the Ethiopian rift are under investigation by scientists from Belgium, Ethiopia, Poland and the United States with support from the Natl Sci Foundation (Grant GS-27325 to Fred Wendorf) and the Inst for the Study of Earth and Man at SMU.

Efforts are being concentrated on geochronology (Albritton, 1973; Laury and Albritton, in press) and paleolithic archaeology (Wendorf and Schild, 1973) of Quaternary volcanics and sediments around $W$ half of Lake Ziway in Shoa Prov. 


\section{SMU-60. Modern Bulinus shells}

$149.7 \pm 0.5 \%$ modern

Snail shells from shore of Lake Ziway at village of Ziway $\left(7^{\circ} 56^{\prime} 18^{\prime \prime}\right.$ N, $38^{\circ} 43^{\prime} 24^{\prime \prime}$ E) Shoa Prov. Coll 1973 by R Daugherty and subm 1973 by $\mathrm{C}$ V Haynes. Comment: analysis reflects nuclear-age atmospheric content of ${ }^{14} \mathrm{C}$, indicating that no age correction is necessary for dating fossil shells of same species.

\section{Terrace III series}

Shells $(6 \mathrm{VH} 73)$ from lacustrine volcanic ash 0.5 to $1 \mathrm{~m}$ below surface of 3 rd terrace above Lake Ziway $1.7 \mathrm{~km} \mathrm{NE}$ of Abosa village $\left(8^{\circ} 2^{\prime} 6^{\prime \prime} \mathrm{N}\right.$, $38^{\circ} 44^{\prime} 6^{\prime \prime} \mathrm{E}$ ). Several species from same deposit analyzed to cross check for age discrepancies between species and allow for correction via SMU60. Coll and subm 1973 by C C Albritton, R L Laury, and C V Haynes.

SMU-66. Corbicula shells

$7880 \pm 290$

$$
5930 \text { BC }
$$

SMU-68. Melanoides shells

$5570 \pm 90$ 3620 BC

SMU-69. Bulinus shells

$5370 \pm 60$

3420 BC

Comment: SMU-60 indicates that Bulinus shell yields correct date and SMU-68 and -69 indicate Melanoides is within $2 \sigma$ of correct age, but Corbicula shell can be $2500 \mathrm{yr}$ too old.

\section{Latrine pit series}

Shells (5VH73) from upper 2 faunal zones in lacustrine volcanic ash $2 \mathrm{~m}$ below surface of 4 th terrace above Lake Ziway at $\mathrm{S}$ side of Abosa village $\left(8^{\circ} 01^{\prime} 18^{\prime \prime} \mathrm{N}, 38^{\circ} 43^{\prime} 12^{\prime \prime} \mathrm{E}\right)$. Coll and subm 1973 by C C Albritton, R L Laury, and C V Haynes.

SMU-63. Corbicula shells

$9090 \pm 100$

\section{SMU.63. Corbicula shells}

SMU.64. Melanoides shells

\section{$7140 \mathrm{BC}$}

$9330 \pm 100$

Comment: 2 species provide comparable ages despite discrepancy suggested by SMU-66 and -68 .

\section{SMU-65. Bulinus shells}

$$
4800 \pm 70
$$

\section{BC}

\section{SMU-67. Same as SMU-65.}

Shells (4VH73) from 10 to $30 \mathrm{~cm}$ below surface in lacustrine volcanic ash exposed by rd to pantellerite quarry $3.25 \mathrm{~km} \mathrm{~W}$ of Ziway $\left(7^{\circ} 56^{\prime} 30^{\prime \prime}\right.$ $\mathrm{N}, 38^{\circ} 40^{\prime} 30^{\prime \prime} \mathrm{E}$ ). Coll and subm 1973 by C C Albritton, R L Laury, and C V Haynes. Comment: dates are on 2 batches (splits) from same sample. Older value is probably closer to true age. 


\section{SMU.61. Corbicula shells}

Shells (1VH73) from lacustrine volcanic ash exposed 2 to $4 \mathrm{~m}$ above channel in right bank of Bul Bulla $\mathrm{R}$ at missionary school $3.4 \mathrm{~km}$ NE of Adamitullu $\left(7^{\circ} 53^{\prime} 24^{\prime \prime} \mathrm{N}, 38^{\circ} 43^{\prime} 48^{\prime \prime} \mathrm{E}\right)$. Coll and subm 1973 by C C Albritton and C V Haynes. Comment: date is probably minimum because contamination by exchange with nuclear-age $\mathrm{CO}_{2}$ is more critical with older samples.

\section{SMU-72. Locality 19}

$11,510 \pm 110$

Charcoal (9VH73) from $80 \mathrm{~cm}$ below surface in red soil developed in pumiceous lapilli deposit on hillside 9.6km SW of Adamitullu $\left(7^{\circ} 48^{\prime} 36^{\prime \prime}\right.$ N, $38^{\circ} 37^{\prime} \mathrm{E}$ ). Coll and subm 1973 by R L Laury and C V Haynes. Comment: dates episode of ash fall and provides maximum age for soil development on ash.

\section{Macho series}

Samples from archaeologic sites in Macho area $9.3 \mathrm{~km}$ WSW of Adamitullu $\left(7^{\circ} 50^{\prime} \mathrm{N}, 38^{\circ} 36^{\prime} 18^{\prime \prime} \mathrm{E}\right)$. Coll and subm 1973 by $\mathrm{G} \mathrm{K}$ Humphreys, SMU.

\section{SMU-83. Macho Site II}

$$
\begin{array}{r}
230 \\
\text { AD } 1720
\end{array}
$$

Charcoal from fire pit dug through thin pumiceous lapilli deposit overlying yellowish-brown soil on underlying ash. Comment: postdates latest ash fall in Macho area.

\section{SMU-84. Macho Site I}

$$
1540 \pm 60
$$

Burnt stump in yellowish-brown soil in small erosional escarpment. Comment: dates lapilli fall that burned trees.

\section{Armijo Draw series}

\section{ARCHAEOLOGIC SAMPLES}

\section{A. New Mexico}

Samples from preceramic hearths exposed in pipeline trench crossing several tributaries of Armijo Draw near Cerrito Redondo, Sandoval Co, New Mexico. Coll and subm 1968 by P J Mehringer and C V Haynes. Archaeology of area is being studied by C Irwin-Williams (1968).

SMU-55. Hearth \#2 humates

$2210 \pm 40$

Hearth below surficial brown soil in eolian sand and $2.1 \mathrm{~km} \mathrm{~W}$ of Cerrito Redondo (35 25' $\left.05^{\prime \prime} \mathrm{N}, 106^{\circ} 53^{\prime} 50^{\prime \prime} \mathrm{W}\right)$.

\section{SMU.56. Hearth \#3 charcoal}


SMU-57. Humates from SMU-56

Hearth on white sand below surficial brown soil $2.3 \mathrm{~km} \mathrm{~W}$ of Cerrito Redondo ( $\left.35^{\circ} 25^{\prime} 20^{\prime \prime} \mathrm{N}, 106^{\circ} 54^{\prime} \mathrm{W}\right)$.

\section{SMU-20. Hearth \#6 charcoal}

$4000 \pm 60$ 2050 BC

\section{SMU-21. Humates from SMU-20}

$3800 \pm 220$

Hearth with heating stones below truncated red soil in light brown fluvial sand $2 \mathrm{~km} \mathrm{SW}$ of Cerrito Redondo ( $35^{\circ} 24^{\prime} 25^{\prime \prime} \mathrm{N}, 106^{\circ} 53^{\prime} 20^{\prime \prime} \mathrm{W}$ ). Comment: humates dates are consistently too young, hence SMU-55 is minimum for preceramic occupation of Armijo area.

SMU-58. Humates from charcoal

$3190 \pm 80$

Finely divided charcoal from hearth (11-1) in red soil in eolian sand on pediment surface $16 \mathrm{~km}$ SE of Belen $\left(34^{\circ} 35^{\prime} \mathrm{N}, 106^{\circ} 40^{\prime} \mathrm{W}\right)$ Valencia Co, New Mexico. Folsom and Bajada artifacts found on surface. Coll and subm 1966 by E Baker and C V Haynes. Comment: charcoal was insufficient for analysis and humate date is minimum for Archaic occupation.

\section{Waso series}

$$
\text { B. Ethiopia }
$$

Samples from archaeologic site on hill top $8.75 \mathrm{~km} \mathrm{SW}$ of Adamitullu ( $\left.7^{\circ} 48^{\prime} 48^{\prime \prime} \mathrm{N}, 38^{\circ} 37^{\prime} 30^{\prime \prime} \mathrm{E}\right)$. Coll and subm 1973 by G K Humphreys.

\section{SMU.85. Waso Site I}

$$
\begin{array}{r}
1350 \pm 40 \\
A D 600
\end{array}
$$

Burnt stump in red soil with root extending down from contact with overlying pumice lapilli deposit. Comment: dates ash fall that burned trees. Difference from SMU-84 is possibly due to different ages of trees.

\section{SMU-86. Waso Site III}

$10,330 \pm 90$

Charcoal from late Stone age site in red soil in volcanic ash and $10 \mathrm{~cm}$ below contact with overlying pumice lapilli deposit. Comment: dates late Stone age occupation during ash deposition either before or during early stage of red soil development.

\section{Aqev Spring series}

$$
\text { C. Israel }
$$

Charcoal from a Late Levantine Upper Paleolithic site (E22D31), $4.5 \mathrm{~km} \mathrm{SE}$ of Midrasha Sde Boker $\left(30^{\circ} 49^{\prime} 02^{\prime \prime} \mathrm{N}, 34^{\circ} 48^{\prime} 39^{\prime \prime} \mathrm{E}\right)$, Negev, Israel. Exposed in wadi terrace in tributary of Nahal Zin. Coll and subm 1971 by A E Marks, SMU.

SMU.6. 30 to $40 \mathrm{~cm}$ depth 


\section{SMU-8. 45 to $50 \mathrm{~cm}$ depth}

$17,390 \pm 560$

15,440 вC

SMU-5. 50 to $55 \mathrm{~cm}$ depth

$19,980 \pm 1200$

18,080 BC

Comment (AEM): SMU-6 and -8 agree well with previous dates; I-5494 and -5495 (R, 1973, v 15, p 295). SMU-5 appears aberrant but overlaps with other dates at $2 \sigma$.

\section{SMU-7. Ein Avdat}

$18,840 \pm 680$

$16,890 \mathrm{BC}$

Charcoal from fire pit at Geometric Kebaran "A" site (E22D5) on a terrace of Nahal Zin, near spring of Avdat, $0.8 \mathrm{~km} \mathrm{SW}$ of Midrasha Sde Boker $\left(30^{\circ} 51^{\prime} 24^{\prime \prime} \mathrm{N}, 34^{\circ} 46^{\prime} 31^{\prime \prime} \mathrm{E}\right)$, Negev, Israel. Exposed at $30 \mathrm{~cm}$ depth. Coll and subm 1971 by A E Marks. Comment (AEM): date is questionable given conflicts with previous dates; Tx-1121 (R, 1972, v 14, p 484) and I-5498 (R, 1973, v 15, p 296). No 2 dates are consistent.

\section{Har Harif series}

Charcoal from midden at Natufian site Rosh Horesha (E22G7) in Nahal Horesha, 26km WSW of Mitzpe Ramon $\left(30^{\circ} 30^{\prime} 50^{\prime \prime} \mathrm{N}, 34^{\circ} 30^{\prime}\right.$ $\left.40^{\prime \prime} \mathrm{E}\right)$, Negev, Israel. Coll and subm 1971 by A E Marks.

\section{SMU-9. Feature 13,35 to $45 \mathrm{~cm}$}

$$
\begin{gathered}
10,490 \pm 430 \\
8540 \text { BC }
\end{gathered}
$$

\section{SMU-10. Features $15 \& 16,35$ to $45 \mathrm{~cm}$}

$$
\begin{gathered}
10,880 \\
\mathbf{8 9 3 0} \mathrm{BC}
\end{gathered}
$$

Comment (AEM): dates seem acceptable in light of other Natufian dates, indicating Natufian was not significantly later in Negev than in $\mathrm{N}$, although typologically this site is not "Early Natufian". Dates are slightly younger than I-5496 (R, 1973, v 15, p 295) from same site.

\section{SMU-3. Nahal Zin}

$8900 \pm 180$

$6950 \mathrm{BC}$

Charcoal from large fire pit in pre-Pottery Neolithic site Nahal Divshon (E22D1) in floor of Nahal Zin, $1 \mathrm{~km}$ SSW of Midrasha Sde Boker $\left(30^{\circ} 50^{\prime} 30^{\prime \prime} \mathrm{N}, 34^{\circ} 47^{\prime} 10^{\prime \prime} \mathrm{E}\right)$, Negev, Israel. Coll and subm 1971 by A E Marks. Comment (AEM): date agrees with I-5501 (R, 1973, v 15, p 296) and Tx-1123 (R, 1972, v 16, p 484) from same site.

\section{Wadi Halfa series}

$$
\text { D. Sudan }
$$

Charcoal from Site DIW-50 in post-Arkin formation silts along W bank of Nile R 4.0km N of Wadi Halfa $\left(22^{\circ} 00^{\prime} 30^{\prime \prime} \mathrm{N}, 31^{\circ} 20^{\prime} 15^{\prime \prime} \mathrm{E}\right)$ Sudanese Nubia. Coll 1964 by W Chmielewska and subm 1971 by F Wendorf, SMU.

\section{SMU-1. Trench 1, 5CH}

$5410 \pm 150$ $\mathbf{3 4 6 0}$ BC 
SMU-2. Trench 1, 7CH

$5880 \pm 150$

$3930 \mathrm{BC}$

Comment (FW): previous dates for same cultural level are $5600 \pm 200$ (WSU-174). See Chmielewska, in Wendorf (1968).

\section{SMU-4. Trench 10 CH (DIW-53)}

$7910 \pm 120$

Charcoal from fire pit in post-Arkin formation silt along $\mathrm{W}$ bank Nile R $3.9 \mathrm{~km} \mathrm{~N}$ of Wadi Halfa $\left(22^{\circ} 00^{\prime} 30^{\prime \prime} \mathrm{N}, 31^{\circ} 22^{\prime} 12^{\prime \prime} \mathrm{E}\right)$ Sudanese Nubia. Coll 1964 by W Chmielewska and R Schild and subm 1972 by $\mathrm{F}$ Wendorf. Comment (FW): should be younger than $7440 \pm 180 \mathrm{BC}$ (WSU175) and older than $3650 \pm 200 \mathrm{BC}$ (WSU-174). See Schild et al, in Wendorf (1968).

\section{REFFRENCFS}

Albritton, C C, Jr, 1973, Geological setting, in: Wendorf and Schild, A middle Stone age sequence from the Central Rift Valley, Ethiopia; Polish Acad (in press).

Broecker, W S, 1957, Application of radiocarbon oceanography and climatic chronology: PhD dissert, Columbia Univ, New York.

Haas, $\mathrm{H}$ and Haynes, C V, Optimization of a liquid scintillation counter for radiocarbon dating of small samples: in press.

Haynes, C V and Hemmings, E T, 1968, Mammoth-bone shaft wrench from Murray Springs, Arizona: Science, v 139, p 186-187.

Hemmings, E T, 1970, Early man in the San Pedro Valley, Arizona: PhD dissert, Univ Arizona, $296 \mathrm{p}$.

Irwin-Williams, C, 1968, Archaic culture history in the southwestern United States, in: Early man in western North America, Symposium SW Anthropol Assoc, Eastern New Mexico Univ Contr Anthropol 1, no. 4, p 48-54.

Laury, R L and Albritton, C C, Jr, Preliminary geology of middle Stone age sites in Central Ethiopian Rift Valley, in press.

Noakes, J E, King, S M, and Stipp, J J, 1965, Chemical and counting advances in liquid scintillation age dating: 6 th internatl conf on radiocarbon and tritium dating Proc, Pullman, Washington, 1965, USAEC Conf-650652, p 68-92.

Slaughter, B H, and Hoover, B R, 1963, Sulphur River formation and the Pleistocene mammals of the Ben Franklin local fauna: Graduate Research Center Jour, v 31,
p 132-148.

Valastro, S E, Davis, E M, and Varela, A G, 1972, University of Texas at Austin radiocarbon dates IX, Radiocarbon, v 14, p $461-485$.

Wendorf, Fred, 1968, The Prehistory of Nubia: Fort Burgwin Research Center and Southern Methodist Univ Press, Dallas, Texas, $2 \mathrm{v}$.

Wendorf, Fred and Schild, R, 1973, A middle Stone age sequence from the Central Rift Valley, Ethiopia: Polish Acad (in press).

Wood, W R and McMillan, R B (eds), Prehistoric man and his environment: a case study in the Ozark highlands, New York, Academic Press, in press. 